\title{
Effect of Symptomatic Treatment Given to Patients Diagnosed with Upper Respiratory Tract Infection in Emergency Department to Prescription Drug Use
}

\author{
(1) Abdullah Osman Koçak ${ }^{1}$, (1) Ayça Çalbay ${ }^{1}$, (1) Hülya Sevil'2, (D) Atıf Bayramoğlu¹, (1) ilker Akbaș ${ }^{1}$, (D) Alparslan Ünlü ${ }^{1}$, \\ (1) Burak Katipoğlu³
}

1Department of Emergency Medicine, Atatürk University, Erzurum, Turkey

${ }^{2}$ Clinic of Emergency Medicine, Erzurum Training and Research Hospital, Erzurum, Turkey

${ }^{3}$ Clinic of Emergency Medicine, Ankara Training and Research Hospital, Ankara, Turkey

\begin{abstract}
Aim: This study aimed to investigate the effect of symptomatic treatment administered in the emergency department on the purchasing behavior for prescribed medicines among patients diagnosed with an emergency upper respiratory tract infection (URTI).

Materials and Methods: This retrospective study was conducted among patients admitted to the emergency department clinic of Atatürk University in March 2016 who were discharged with a diagnosis of URTI. In total, 1,104 patients were included in the study. Using the pharmacy medulla system of the Turkish Social Security Institution, cases of patients taking prescriptions written to them were recorded. Data entry and statistical analysis were performed using SPSS statistical data program.

Results: A total of 1,104 patients were examined; of them, 553 received an intervention (50.09\%), 543 (49.18\%) received no intervention, and eight patients (0.72\%) were identified as having missing data. It was determined that $336(60.75 \%)$ of the patients receiving an intervention received a prescription written for them, whereas 207 (37.43\%) did not.

Conclusion: Patients who are discharged from the emergency service with a diagnosis of URI do not receive prescriptions that will help with their actual treatment if they received any interventional therapy on arrival.
\end{abstract}

Keywords: Upper respiratory tract infection, symptomatic treatment, emergency department

\section{Introduction}

Upper respiratory tract consists of nose, tonsillar, adenoid, farinx, larinx, paranasal sinuses and ear which are above the larynx. Pharyngitis, rhinosinusitis, and flu are the most common causes of upper respiratory tract infections (URIs) as well as the most frequent causes of adulthood (1,2). Infections can be viral, bacterial or mixed infections and/or acute or chronic (3).

Flu is the most common cause of acute illness in the United States of America (USA) and the world (4). Among the underlying causes, many virus families can be blamed. It may be a single factor or may be multifactorial (5). Every year in the USA, 3\% of the patients are referred to the clinic and $30 \%$ of these patients are prescribed antibiotics (5).
Pharyngitis causes an annual hospitalization of nearly 12 million people in the US. It constitutes 1 to $2 \%$ of remote care patients (6). This disease is prescribed in each of the clinical applications. Most antibiotics are unnecessary in most patients, but prescriptions often include antibiotics (7).

Acute rhinosinusitis occurs in the presence of viral infections, allergies, or irritants that cause mucosal tissue inflammation in the nasal and paranasal sinus cavities. More than 4.3 million patients are diagnosed with sinusitis per year. More than $80 \%$ of these patients are receiving prescription treatment (8).

Among the most common preliminary diagnoses and complaints in a study conducted in 214,010 patients in a 6.5-year period in a 
university emergency room in İzmir, acute nasopharyngitis, sore throat and dizziness were detected (9).

Our purpose in this study is; to investigate the effect of the symptomatic treatments we give our patients with the URI of the emergency department to the official prescriptions which include the actual treatment of the patients.

\section{Materials and Methods}

\section{Study Design}

This retrospective study was planned between 01 March and 31 March 2016 by taking 1,104 patients who were admitted to the emergency department of Atatürk University with complaints such as fatigue, fever, sore throat, earache, headache, dizziness, cough and discharge with URI. Patients' vital signs, treatments given from the emergency room intramuscular and intravenous (im, iv), duration of stay and prescriptions were recorded after the investigation of these patients' file. Turkish Social Security Institution pharmacy medulla tracking system has been checked whether the patients have taken the T.C. ID numbers and received prescription drug treatment written to them.

\section{Data Collection}

Patients who were admitted with complaints such as fatigue, fever, sore throat, earache, headache, dizziness, cough, over 18 years of age and discharged with a URI were included in the study.

\section{Identification of "Missed Cases"}

Eight patients $(0.72 \%)$ with missing information about the treatment given to the patient and six patients $(0.54 \%)$ who were unable to obtain information from the pharmacy system were accepted as missing data in the patient files filled in the emergency service.

\section{Statistical Analysis}

Statistical analysis of the study was performed with the SPSS Version 20.0 program (SPSS Inc., Chicago, Illinois, USA). Chisquare $\left(x^{2}\right)$ test was used for comparison of categorical data. Student's t-test was used to compare numerical data between groups. A value of $p<0.05$ was considered statistically significant.

\section{Results}

Five hundred and forty-three (49.1\%) of the 1,104 patients who were included from the study were treated from emergency room and 336 (34.3\%) of these population took their prescription (Table 1).

The relationship between the groups was statistically significant $(p=0, p<0.05)$.

\begin{tabular}{|l|l|l|l|l|}
\hline \multicolumn{6}{|c|}{ Table 1. Demographic characteristics of groups } \\
\hline & $\begin{array}{l}\text { ER therapy } \\
(-)\end{array}$ & $\begin{array}{l}\text { ER therapy } \\
(+)\end{array}$ & $\begin{array}{l}\text { ER therapy } \\
\text { missing }\end{array}$ & Total \\
\hline Prescription (+) & 379 & 336 & 2 & 717 \\
\hline Prescription (-) & 173 & 207 & 1 & 381 \\
\hline $\begin{array}{l}\text { Prescription } \\
\text { missing }\end{array}$ & 1 & 0 & 5 & 6 \\
\hline Total & $\mathbf{5 5 3}$ & $\mathbf{5 4 3}$ & $\mathbf{8}$ & $\mathbf{1 , 1 0 4}$ \\
\hline ER: Estrogen receptor & & & \\
\hline
\end{tabular}

\section{Discussion}

Emergency service is being used improperly by patients with complaints of URIs, those who want to prescribe, and patients with simple pain (10). Emergency service is the most frequent cause of the first three diseases; J03/acute tonsillitis, J39/other upper respiratory tract diseases and J02/acute pharyngitis, respectively. Similarly, although our clinic is a tertiary health care organization, only about $10 \%$ of all urgent care applications are attributable to patients with URI complaints only. In addition, this patient group asks for urgent symptomatic treatment when the emergency department visits. Such demands, which are the immediate urgency of emergency service employees and steal a life-threatening illness-care time, both reduce the work and maintenance of service workers and increase work intensity (11). Our study showed that clinicians' attempts at this group of patients negatively affected the use of prescribed medicines, which constituted the main component of the treatment. Whether this condition is beneficial for the patient is questionable.

URI's include infections of anatomical structures that are above the larynx. Rhinitis, acute tonsillopharyngitis, acute rhinosinusitis, colds are mostly caused by viruses; The most common cause of acute otitis media is Streptococcus pneumoniae (30-50\%), H. influenzae (15-30\%) and M. catarrhalis (5-20\%) (12). Patients are admitted to emergency services with a number of nonspecific symptoms such as headache, weakness, sore throat, fever, sensation of fullness in the forehead and ear, nasal discharge, discomfort and general body pain (13). Intervention is expected in these complaints, which is the emergency department where the treatment of many diseases is given and many different symptoms are relieved (10).

There are many life-threatening diseases such as pulmonary embolism and heart failure, and some criteria such as light criteria are used in the management of pulmonary embolism. Biomarkers are sometimes used in the diagnosis of these diseases, among which NT-pro-BNP is one of the ideal biomarkers to be used clinically in the diagnosis of pulmonary embolism (14). 
Edirne et al. (15) Showed that emergency medical service referral criteria consisted of short-term medical observation, intervention, supportive treatment and inpatient treatment.

Special diagnostic methods of emergency departments, strong perception of emergencies, special care for treatment, and the ability to direct them to other health care providers are important reasons for their improper use $(16,17)$.

\section{Conclusion}

As a result, patients with URIs receiving emergency services and/ or iv treatments increase the workload of emergency services that are already intensively working and reduce the rate of prescription of medicines that will provide the actual treatment of the patients. Imbalance and im or iv treatments for symptoms do not constitute the actual treatment of the diseases and are not superior to the prescribed treatments. Patients with temporary relief in their symptoms do not get their prescriptions written. And the data obtained in this study supports us.

\section{Ethics}

Ethics Committee Approval: Since this retrospective study was conducted between 01 March and 31 March 2016, and ethics committee approval was not necessary for retrospective studies in that time, ethics committee approval was not taken.

Informed Consent: Retrospective study.

Peer-review: Externally peer-reviewed.

\section{Authorship Contributions}

Surgical and Medical Practices: A.Ü., İ.A., Concept: A.O.K., H.S., Design: A.Ç., I.A., Data Collection or Processing: I.A., A.B., Analysis or Interpretation: H.S., A.O.K., Literature Search: A.B., Writing: B.K., A.Ç.

Conflict of Interest: No conflict of interest was declared by the authors.

Financial Disclosure: The authors declared that this study received no financial support.

\section{References}

1. Parri FM, Neu HC, Connelly JV. Infectious diseases. In: Rakel RE, editor. Textbook of Family Practice. 5th ed. Philadelphia: W.B. Saunders Company; 1995.p.317-92.

2. Purssell E. Upper respiratory tract infection in infants from a nutritional perspective. J Fam Health Care. 2009;19:164-8.

3. Seçmeer G, Devrim I. Üst solunum yolu infeksiyonlarında medikal tedavideki yenilikler. Hacettepe Tıp Derg. 2006;37:194-201.

4. Gonzales R, Bartlett JG, Besser RE, Hickner JM, Hoffman JR, Sande MA. American Academy of Family Physicians Principles of appropriate antibiotic use for treatment of nonspecific upper respiratory tract infections in adults: background. Ann Intern Med. 2001;134:490-4.

5. Heikkinen T, Järvinen A. The common cold. Lancet. 2003;361:51-9.

6. Schappert SM, Rechtsteiner EA. Ambulatory medical care utilization estimates for 2006. Natl Health Stat Report. 2008;1-29.

7. Barnett ML, Linder JA. Antibiotic prescribing to adults with sore throat in the United States. 1997-2010. JAMA Intern Med. 2014:174;138-40.

8. Fairlie T, Shapiro DJ, Hersh AL, Hicks LA. National trends in visit rates and antibiotic prescribing for adults with acute sinusitis [Letter]. Arch Intern Med. 2012;172:1513-4

9. İzmir Tabip Odası Acil Sağlık Hizmetleri Çalıștayı 26.02.2014 Çalıștay Raporu https://docplayer.biz.tr/1940729-Izmir-tabip-odasi-acil-saglik-hizmetlericalistayi-26-02-2014-calistay-raporu.htm

10. Simsek P, Gursoy A. Turkish health care providers' views on inappropriate use of emergency department: Who, when and why? Int Emerg Nurs. 2016;27:316. doi: 10.1016/j.ienj.2015.11.004. [Epub 2015 Dec 31].

11. Brim C. A descriptiveanalysis of thenon-urgentuse of emergencydepartments J Nurs Res. 2008;15:72-88.

12. Leblebicioglu H. Üst solunum yolu enfeksiyonları. Akılcı Antibiyotik Kullanımı ve Erișkinde Toplumdan Edinilmiș Enfeksiyonlar Sempozyum Dizisi No: 31, Nov 2002; p.167-82.

13. Harris AM, Hicks LA, Qaseem A, for the High Value Care Task Force of the American College of Physicians and for the Centers for Disease Control and Prevention. Appropriate Antibiotic Use for Acute Respiratory Tract Infection in Adults: Advice for High-Value Care From the American College of Physicians and the Centers for Disease Control and Prevention. Ann Int Med. 2016:64:425-34.

14. Teke T, Yesildag K. The New Biomarkers Used in the Differentiation Between Transudate and Exudate Pleural Effusions. Eurasian J Crit Care. 2019;1:10510

15. Edirne T, Edirne Y, Atmaca B, Keskin S. Characteristics of the patients who visited Emergency Department of Yüzüncü Yıl University Medicine Faculty Hospital. Van Med J. 2008;15:107-11.

16. Callen JL, Blundell L, Prgomet M. Emergency department use in a rural Australian setting: are the factors prompting attendance. Aust Health Rev. 2008;32:710-20.

17. Carret MLV, Anaclaudia G, Fassa AG, Kawachi I. Demand for emergency health service: factors associated with inappropriate use. BMC Health Serv Res. 2007;7:131. 